\title{
Waste Aluminum Application as Energy Valorization for Hydrogen Fuel Cells for Mobile Low Power Machines Applications
}

\author{
Xavier Salueña-Berna ${ }^{1} \mathbb{D}$, Marc Marín-Genescà ${ }^{2, * \mathbb{C}}$, Lluís Massagués Vidal ${ }^{3}$ and José M. Dagà-Monmany ${ }^{4}$ \\ 1 Mechanical Engineering Department, ESEIAAT-UPC, Colom 1, 08222 Terrassa, Spain; xavier.saluena@upc.edu \\ 2 Mechanical Engineering Department, ETSEQ-URV, Països Catalans 26, 43007 Tarragona, Spain \\ 3 Electrical Engineering Department, ETSE-URV, Països Catalans 26, 43007 Tarragona, Spain; \\ lluis.massagues@urv.cat \\ 4 Chemical Engineering Department, ESEIAAT-UPC, Colom 1, 08222 Terrassa, Spain; jose.maria.daga@upc.edu \\ * Correspondence: marc.marin@urv.cat
}

Citation: Salueña-Berna, $\mathrm{X}$;

Marín-Genescà, M.; Massagués Vidal, L.; Dagà-Monmany, J.M. Waste Aluminum Application as Energy Valorization for Hydrogen Fuel Cells for Mobile Low Power Machines Applications. Materials 2021, 14, 7323. https://doi.org/10.3390/ma14237323

Academic Editor: Benjamín Solsona

Received: 29 September 2021

Accepted: 27 November 2021

Published: 30 November 2021

Publisher's Note: MDPI stays neutral with regard to jurisdictional claims in published maps and institutional affiliations.

Copyright: (c) 2021 by the authors. Licensee MDPI, Basel, Switzerland. This article is an open access article distributed under the terms and conditions of the Creative Commons Attribution (CC BY) license (https:/ / creativecommons.org/licenses/by/ $4.0 /)$.

\begin{abstract}
This article proposes a new model of power supply for mobile low power machines applications, between $10 \mathrm{~W}$ and $30 \mathrm{~W}$, such as radio-controlled (RC) electric cars. This power supply is based on general hydrogen from residual aluminum and water with $\mathrm{NaOH}$, so it is proposed energy valorization of aluminum waste. In the present research, a theoretical model allows us to predict the requested aluminum surface and the required flow of hydrogen has been developed, also considering, in addition to the geometry and purity of the material, two key variables as the temperature and the molarity of the alkaline solution used in the hydrogen production process. Focusing on hydrogen production, isopropyl alcohol plays a key role in the reactor's fuel cell vehicle as it filters out $\mathrm{NaOH}$ particles and maintains a constant flow of hydrogen for the operation of the machine, keeping the reactor temperature controlled. Finally, a comparison of the theoretical and experimental data has been used to validate the developed model using aluminum sheets from ring cans to generate hydrogen, which will be used as a source of hydrogen in a power fuel cell of an RC car. Finally, the manuscript shows the parts of the vehicle's powertrain, its behavior, and mode of operation.
\end{abstract}

Keywords: hydrogen; aluminum waste; isopropyl alcohol; hydrogen generation; hydrogen flow rate; sustainability; fuel cell; hydrogen machines

\section{Introduction}

There are low-power machines such as radio-controlled electric cars on the market with a fuel cell. The advantage over battery machines is the shorter electric recharging times, which makes their autonomy longer [1]. The hydrogen storage necessary for lowpower machines' fuel cells is usually carried out with metal hydride tanks or with small metal pressurized hydrogen tanks [2], and the generation of hydrogen is by electrolysis, in an external device from electricity from the electrical network [3], from biological production [4], by fossil fuel reforming [5,6] or pyrolysis from gas natural, heavy oils, naphtha or coal, and the hydrogen is distributed commercially from pressure cylinders $[7,8]$. Researchers have proposed other methods to obtain hydrogen by hydrolysis of metal (aluminum or magnesium) or metal hydride [9]. There are currently a lot of studies in chemical hydrides, including ammonia [10], ammonia borane, metal boron hydride, formic acid, hydrazine hydrate, aromatic compounds, or sodium borohydride [11] to obtain it in situ [12]. There is even an article where ammonia borane is used to feed a fuel cell of $30 \mathrm{~W}$, but not in a machine due to the complexity of this method to be installed on small machines [13].

One of the current methods to facilitate the aluminum-water reaction from liquid aluminum particles uses gallium [14] or activated Ga-In-Sn-Bi alloys [15], but these sys- 
tems require previous preparations, are expensive and the associated wastes must be processed [16]. The other methods used to facilitate the aluminum-water reaction consist of the aluminum introduction into an alkaline (or acid) solution to eliminate the surface oxide layer and subsequently the posterior layers of aluminum hydroxide that are formed. In some cases, promoters, such as oxides and salts, are used to reduce the amount of alkali needed, but in some cases the chemical reactor should be warmed up [17] at the startup, and sometimes the precipitated residue must be processed in recycling [18].

In this article, a sustainable method is proposed to generate high purity hydrogen, in situ, from cheap waste aluminum sheets, such as rings cans, and an alkaline solution by the aluminum-water reaction. The residue (sodium aluminate) from this system is not only fully recyclable, but with renewable energy, it can be transformed into the original products (aluminum, $\mathrm{NaOH}$ and water) since no other catalyst is used [19].

In the bibliography, there are several cases of industrial prototypes where this technology is applied, although it usually starts with high purity aluminum powder in the size order of microns and is very expensive [20]. In such prototypes, aluminum is usually dosed, which enters the reactor, to control and predict the hydrogen flow produced [21]. Generally, in fuel cells, it is required that said flow to be constant over time [22] since they work at nominal power in parallel with an auxiliary battery, which absorbs the electrical energy excess generated, not consumed, and besides, it regulates the voltage [23].

Technologically, and more in a small vehicle, it is difficult to dose a solid to control the flow [24], so initially, all the aluminum and the alkaline solution are inside the reactor. When aluminum reacts with water in an alkaline medium, the reaction is exothermic [25] and the temperature rises, so a no constant flow rate of hydrogen is produced because the flow rate increases strongly with the temperature [26]. When operating in this way, it is necessary to have an intermediate tank to store the surplus hydrogen, which is the difference between the flow rate generated by the reactor and that consumed by the machine fuel cell. Another drawback of the aluminum-water reaction in an alkaline medium is that although the hydrogen obtained is of high purity [27], it tends to carry $\mathrm{NaOH}$ particles and water vapor [28], which could alter the operation and durability of the fuel cell [29].

The current article proposes an alternative method for obtaining hydrogen in an alcoholic medium (isopropyl alcohol), in a controlled manner. In another article, we explain how we tested different alcohols to check which was the optimal one [30]. A model obtained in a theoretical-experimental way is proposed, capable of characterizing the hydrogen flow according to the: chip dimensions, the aluminum active surface, solution molarity and temperature. Likewise, it describes how alcohol affects the reaction, carrying out a comparative analysis of the obtained hydrogen flow rates and analyzing the purity of the hydrogen. Finally, the knowledge acquired in the accurate feeding with soda rings a fuel cell of a radio-controlled car, called dAlH2orean, has been applied.

The main novelty of this work is the simplification of the hydrogen generator, thanks to alcohol, which allows it to be mounted in a small low-power machine since no heavy exchangers are needed to keep the flow controlled and neither are expensive filters to eliminate the contaminants that can damage the fuel cell and its application.

\section{Materials, Theoretical Models and Tests}

\subsection{Materials}

The aluminum used to obtain the theoretical-experimental model consists of a $0.5 \mathrm{~mm}$ thick aluminum sheet according to ISO209: 2007 for aluminum with $99.5 \%$ purity. The aluminum is the same as that used in the manufacturing of soda rings. A soda ring is nothing more than an aluminum sheet of constant thickness, cut and folded, so the behavior will be similar. Regarding sodium hydroxide, the analysis was developed with a solution of sodium hydroxide from $1 \mathrm{M}$ to $10 \mathrm{M}$ in test 1 and $7.5 \mathrm{M}$ in the rest of the tests, starting from $50 \% w / w$ solutions (PANREAC 142404.0716) and distilled water.

Finally, regarding alcohol, isopropyl with a $99 \%$ purity has been used. The boiling alcohol temperature must be higher than $70^{\circ} \mathrm{C}$, and since the chemical reaction is exother- 
mic if alcohol is not used, the reactor temperature could surpass the $80^{\circ} \mathrm{C}$, and if the alcohol boiling point was inferior to that of isopropyl alcohol, it could completely vaporize at a lower temperature and not perform its function. Because of the isopropyl alcohol presence, the temperature remains in the range from $50{ }^{\circ} \mathrm{C}$ to $60{ }^{\circ} \mathrm{C}$ inside the reactor. At that temperature range, bayerite is formed [31], and if it were higher, boehmite would form and the theoretical model used could be not appropriated.

\subsection{Theoretical Kinetic Model}

Chemical Reactions.

The chemical reaction to obtain hydrogen from water-aluminum mix [32] is obtained by next Equation (1).

$$
2 \mathrm{Al}(\mathrm{s})+6 \mathrm{H}_{2} \mathrm{O}(\mathrm{L}) \rightarrow 2 \mathrm{Al}(\mathrm{OH})_{3}(\mathrm{~s})+3 \mathrm{H}_{2}(\mathrm{~g})
$$

Solid $\mathrm{Al}(\mathrm{OH})_{3}$ creates a surface layer that prevents water from reacting with the aluminum, becoming passivated solution. In order to avoid passivation [33], the reaction will be performed by an $\mathrm{NaOH}$ alkaline solution, and finally $\mathrm{Al}(\mathrm{OH})_{3}$ is transformed into aqueous $\mathrm{Na} \mathrm{Al}(\mathrm{OH})_{4}$, leaving Equation (2).

$$
2 \mathrm{Al}(\mathrm{s})+6 \mathrm{H}_{2} \mathrm{O}(\mathrm{L})+2 \mathrm{NaOH}(\mathrm{aq}) \rightarrow 2 \mathrm{NaAl}(\mathrm{OH})_{4}(\mathrm{aq})+3 \mathrm{H}_{2}(\mathrm{~g})
$$

According to the bibliography [34], the hydrogen flow rate, and therefore the reduction in the mass of the sheet, is proportional to the apparent rate constant of the reaction $\mathrm{k}$. The hydrogen flow rate is also proportional to the active surface of the aluminum and the concentration of the solution. To formulate the kinetic model, it is assumed that aluminum is the limiting reactant, and therefore the flow rate will depend on the active surface of the aluminum. This hypothesis serves only as a starting point for the study since the surface can be reduced by its partial passivation. The active surface decreases according to time since aluminum is transformed into $\mathrm{Al}(\mathrm{OH})_{3}$, and also depending on the shape of the original chip or specimen. One of the contributions of the present research is the modeling of the active surface for the form of a simple sheet prismatic shape, and which the size is needed to produce the minimum hydrogen flow rate to be consumed by the fuel cell.

\subsubsection{Theoretical Hydrogen Flow Rate}

The previewed hydrogen flow rate $Q_{H_{2}, t}$ is obtained across Equation (1) as a function of the aluminum active surface $\left(S_{A l, t}\right)$, the thickness reduction per surface as time function $(e)$, the weight $M_{A l}$ and density $\rho_{A l}$, assuming ideal gas behavior, can be expressed according to Equation (3), [35].

$$
Q_{H_{2}, t}=\frac{3}{2} \frac{\rho_{A l}}{M_{A l}}\left(\frac{R T}{P}\right)\left(S_{A l, t} \cdot e\right)
$$

\subsubsection{Aluminum Active Surface}

The material is aluminum waste in sheet form. A model has been developed, which describes the active surface of the aluminum foil as a function of time, assuming that the foil is ideally prismatic. An aluminum sheet (Figure 1 ) of measure $L \cdot a \cdot p$ is considered, where the thickness: $p, a$ is the width and length is $L$. The speed at which aluminum consumes is called corrosion rate $R c$.

We assume that there is a reduction in the thickness per surface, $e(\mathrm{~mm} /$ minutes), that depends on time $t$. This is applied to all the sheet surfaces (Figure 1) until the thickness $p$ is used up, which will be less. 


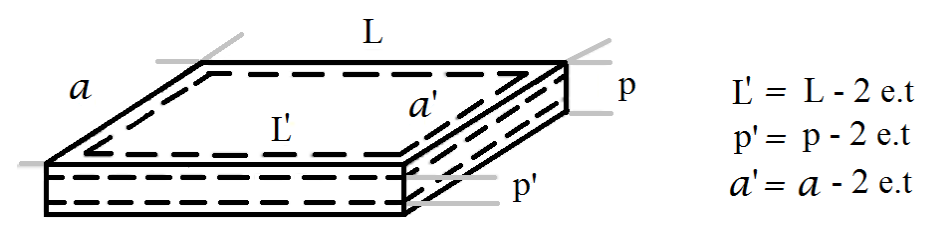

Figure 1. Theoretical representation of corrosion rate of a sheet by the reaction of aluminum-water.

The active surface of the sheet as a function of the initial aluminum mass $W_{A l, 0}$, purity $\eta$ and density $\rho$ is described by Equation (4).

$$
S_{A l, t}=\frac{2 W_{A l, 0} \eta}{\rho_{A l} L a p}\left[\left(L^{\prime}+a^{\prime}+2 e\right) *\left(p^{\prime}+2 e\right)+\left(L^{\prime} * a^{\prime}\right)\right]
$$

Logically, the sheet lifetime, from when the beginning to react until it is totally consumed, depends on its smallest size $p$, so, its thickness. As the thickness of the sheet is very small, the reduction suffered by the upper and lower faces, $L, a$, is minimal, so that the active surface would suddenly go from a considerable value to zero when the thickness $p^{\prime}=p-2 e t$ equals zero. This happens gradually since in the last phase the sheet floats and disappears from the edges towards the center. The obtained flow rate as time function $Q_{H_{2}, t}$, for a sheet, completing Equation (3) with Equation (4), is determined by Equation (5).

$$
Q_{H_{2}, t}=\frac{3 W_{A l, 0} \eta}{M_{A l} L a p}\left(\frac{R T}{P}\right)-\left[\left(L^{\prime}+a^{\prime}+2 e\right) *\left(p^{\prime}+2 e\right)+\left(L^{\prime} * a^{\prime}\right)\right] \cdot e
$$

Being the theoretical volume of hydrogen $V_{H_{2}}$, produced in a time $t=n$ [minutes], according to Equation (6):

$$
V_{H_{2}}=\frac{3}{2} \frac{\rho_{A l}}{M_{A l}}\left(\frac{R T}{P}\right) \sum_{t=0}^{n}\left(S_{A l, t} \cdot e\right)
$$

The volume of hydrogen (theoretical) $V_{H_{2}}$ for one sheet is given by Equation (7):

$$
V_{H_{2}}=\frac{3 W_{A l, 0} \eta}{M_{A l} L a p}\left(\frac{R T}{P}\right)-\sum_{t=0}^{n}\left[\left(L^{\prime}+a^{\prime}+2 e\right) *\left(p^{\prime}+2 e\right)+\left(L^{\prime} * a^{\prime}\right)\right] \cdot e
$$

The calculation of the thickness reduction per surface $e$ will be made from the determination of the corrosion rate $R c$, which depends on the volume of hydrogen $(\mathrm{mL})$ given in Equation (7), the surface $\left(\mathrm{cm}^{2}\right)$ Equation (4) and time $t(\mathrm{~min})$.

$$
R_{c}=\frac{V_{\mathrm{H}_{2}}}{S \cdot t}
$$

$R c$ depends on the molarity of the solution and the reaction temperature. For each molarity, its value can be determined as a function of temperature by using the Arrhenius equation, Equation (9), where $A$ is the frequency coefficient $\left(\mathrm{mL} \mathrm{cm}^{-2} \mathrm{~min}^{-1}\right), E_{a}$ is the activation energy $\left(\mathrm{kJ} \mathrm{mol}^{-1}\right), R$ is the ideal gas constant $\left(\mathrm{kJ} \mathrm{K}^{-1} \mathrm{~mol}^{-1}\right)$ and $T$ is the temperature (K).

$$
\ln R c=\ln A-\frac{E a}{R T}
$$

The value of $R c$ has been found experimentally from the volume of hydrogen generated. The equation has been found experimentally, through the characteristic graph of the Arrhenius linear model, lnk $\left(\mathrm{min}^{-1}\right)$ vs. $1 / T\left(\mathrm{~K}^{-1}\right)$, and comparing the values obtained experimentally with those given in the bibliography [36-38], and the accepted values are in the range between 42.5 and $68.4 \mathrm{~kJ} / \mathrm{mol}$. From the mean $R c$, through Equation (8), the theoretical thickness reduction $e$ can be calculated for any temperature and molarity inside the studied ranges. 


\subsection{Validation Tests}

Validation of the theoretical model has been performed by using several tests that have been developed to validate the model, that is, to understand how Al 99.5 aluminum sheets react in a caustic soda solution at different molarities, with and without isopropyl alcohol. The tests were carried out in a $500 \mathrm{~mL}$ flask at a constant temperature of $25^{\circ} \mathrm{C}, 40{ }^{\circ} \mathrm{C}$ and $60{ }^{\circ} \mathrm{C} ; 200 \mathrm{~mL}$ in a solution of $\mathrm{NaOH}$ (with or without $100 \mathrm{~mL}$ of isopropyl alcohol, depending on the test) were introduced into the flask. The aluminum specimens were then introduced into the flask keeping a constant temperature, and the flask was hermetically capped, connected to a flowmeter. The aluminum reacted with the solution generating hydrogen, which was cooled to a temperature of $15{ }^{\circ} \mathrm{C}$ before the flow measurement. The test ended when all the aluminum was consumed. Two tests were developed with each sample, obtaining the mean values, and repeating the measurement if the variation exceeded 90\%. In some of the tests, the dimensions the thickness of the sheets was measured at one-minute intervals with a precision micrometer. We have applied the one-factor-atime strategy because the behavior of the thickness reduction as a function of time is not constant over time and the only aim is to find the optimal conditions to achieve the maximum flow rate.

\subsubsection{Test 1: Effect of Molarity}

Through test 1 , it is intended to find experimentally how the reaction behaves as a function of molarity to corroborate Equation (5) and to find the optimal molarity that can decompose the aluminum plate in the shortest possible time to generate the highest hydrogen flow rate.

Aluminum sheets of $20 \times 30 \times 0.5 \mathrm{~mm}^{3}$ were tested at $25^{\circ} \mathrm{C}$ in $\mathrm{NaOH}$ solutions at different molarities $(1 \mathrm{M}, 2 \mathrm{M}, 3 \mathrm{M}, 4 \mathrm{M}, 5 \mathrm{M}, 6 \mathrm{M}, 7 \mathrm{M}, 8 \mathrm{M}, 9 \mathrm{M}$, and $10 \mathrm{M})$. Since the best results have been given for the molarity of 7 and $8 \mathrm{M}$, the following tests were carried out at $7.5 \mathrm{M}$.

\subsubsection{Test 2: Effect of the Dimension of the Sheet}

Using test 2, two experiments were tested to compare the hydrogen generation in the $\mathrm{NaOH}$ solution $(7.5 \mathrm{M})$ at $25{ }^{\circ} \mathrm{C}$ temperature in sheets (foil format) or chips (foil cuttings) to check if the sheets, as in the case of rings, would have the same behavior observed in chips. A $20 \times 30 \times 0.5 \mathrm{~mm}^{3}$ sheet was first tested and later a set of 104 chips of $2.002 \times 2.002 \times 0.5 \mathrm{~mm}^{3}$, so that in the two experiments, both specimens had the same initial theoretical contact surface $\left(1250 \mathrm{~mm}^{2}\right)$. Since the purity of the aluminum was $99.5 \%$, the initial area was $1243.75 \mathrm{~mm}^{2}$.

\subsubsection{Test 3: Temperature Effect}

Through test 3 , the temperature effect in the generation of the hydrogen flow was compared, as well as in the reduction of the thickness of the sheet, to be able to validate Equation (7). Given the same behavior of the sheets or chips, a $20 \times 30 \times 0.5 \mathrm{~mm}^{3}$ sheet in $7.5 \mathrm{M} \mathrm{NaOH}$ solution was used for the test, and we experimented how it would be affected for the temperatures of $25^{\circ} \mathrm{C}, 40^{\circ} \mathrm{C}$ and $60^{\circ} \mathrm{C}$. After that, we performed the experiment with a ring can for the temperatures of $50^{\circ} \mathrm{C}$ and $60^{\circ} \mathrm{C}$ in a $4 \mathrm{M} \mathrm{NaOH}$ solution.

\subsubsection{Test 4: Effect of the Addition of Alcohol}

By test 4, the effect of the addition of alcohol isopropyl in $7.5 \mathrm{M} \mathrm{NaOH}$ solution was compared. For this, a $20 \times 30 \times 0.5 \mathrm{~mm}^{3}$ aluminum foil was processed at $60{ }^{\circ} \mathrm{C}$ temperature, with and then without isopropyl alcohol. 


\subsubsection{Test 5: Hydrogen Purity Analysis}

To obtain the hydrogen percentage, some specimens of one hydrogen liter were generated and then collected, after a purge carried out by a generation of the same gas, in a Tedlar bag. The hydrogen obtained was analyzed through a "Agilent $3000 \mathrm{~A}^{\text {" micro }}$ gas chromatograph equipped with 3 independent modules, each provided with a thermal conductivity detector (TDC) and columns to measure light gases (molecular sieve), light hydrocarbons (with Plot $\mathrm{U}$ ) and oxygenates (Stabil wax). The calibration of the apparatus was made from the hydrogen of $99.999 \%$ purity. Three analyses were performed for each of the collected samples.

\subsubsection{Test 6: Application in a Vehicle Prototype with Hydrogen Fuel Cell}

To demonstrate the validity of the model and its application in the field of engineering, a radio-controlled vehicle has been developed (Figure 2), with a fuel cell whose hydrogen has been generated from aluminum soda rings.

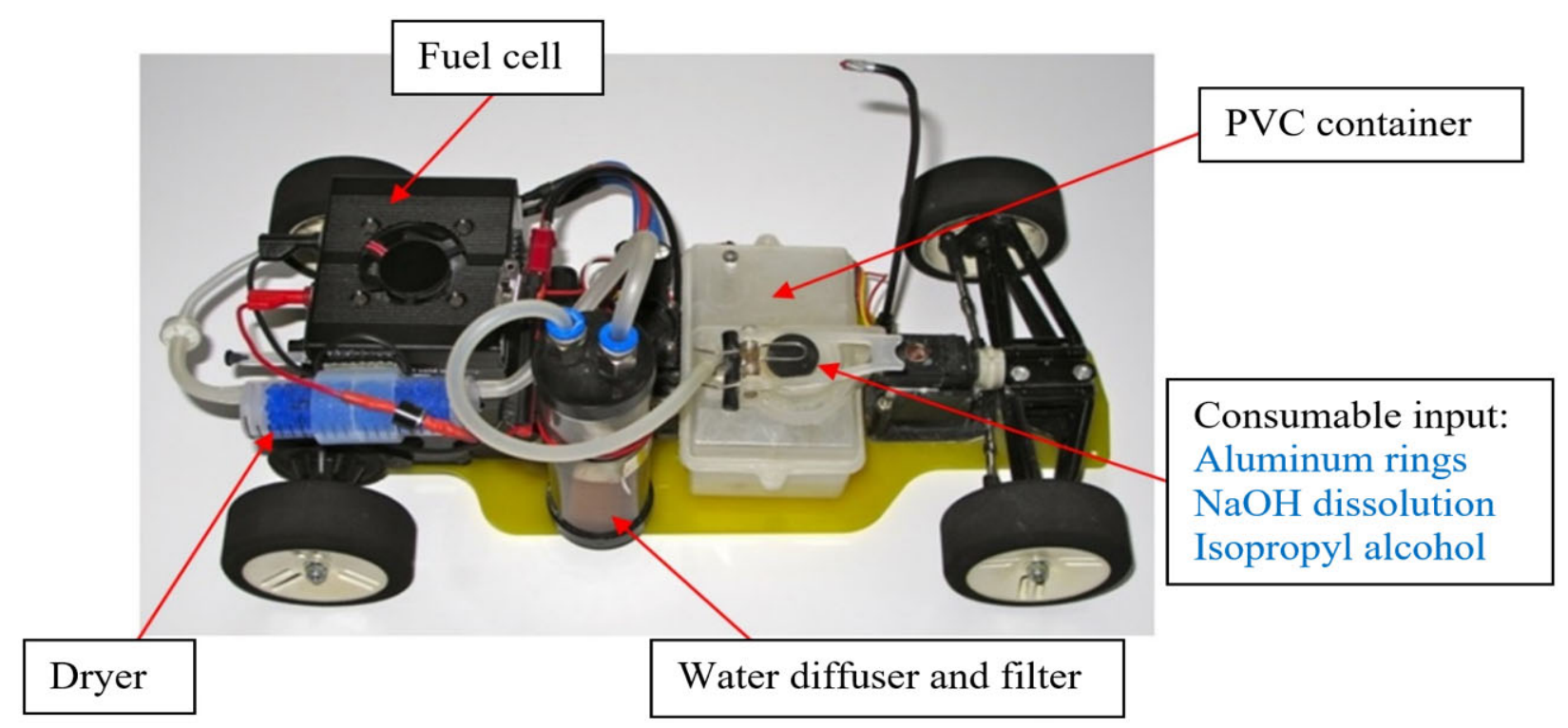

Figure 2. Hydrogen generation, filtering, and drying areas for the fuel cell of an RC car. (Photography: Aleix Llobet).

The fuel cell $\mathrm{H}-12$ used is of the proton exchange membrane (PEM)-type from the company Horizon, whose maximum flow required at 1.5 A-7.8 V [11.7 W] operating power is $150 \mathrm{~mL} / \mathrm{min}$ with $99.995 \%$ purity hydrogen, according to manufacturer's specifications. As the generation system is not completely hermetic and may contain some humidity, the hydrogen is not pure, and therefore it is necessary to leave the outlet of the fuel cell open so that air or humidity does not accumulate inside it because the performance of the battery may decrease. In the $225 \mathrm{~mL}$ PVC tank, 15 soda rings of $0.285 \mathrm{~g}$ each, $100 \mathrm{~mL}$ of $4 \mathrm{M} \mathrm{NaOH}$ solution and $30 \mathrm{~mL}$ of isopropyl alcohol, both preheated to $40{ }^{\circ} \mathrm{C}$, were introduced. Hydrogen, which carried some alcohol vapor, was filtered with a diffuser filter containing $50 \mathrm{~mL}$ of distilled water. At the outlet of the water filter, the hydrogen was dried using silica-gel 3-6 211335.1210 Panreac and introduced into the fuel cell. The fuel cell was installed in parallel, with a protection diode, with a battery made up of 6 AA rechargeable $\mathrm{NiMH} 1.2 \mathrm{~V}$ and $1900 \mathrm{mAh}$ batteries. Both powered a Bycmo Speed-PRO variable speed drive, the radio control receiver, a Mabuchi RS-540SH 4.8-7.2 V motor (Mabuchi Motor Company, Matsudo, Japan) and the servo motor for the steering. In the experiment, the hydrogen flow generated at the filter outlet was measured. 


\section{Results}

\subsection{Trials}

\subsubsection{Effect of Molarity}

In Figure 3, the reduction of the thickness of the sheet per hour is described over $3 \mathrm{~h}$, at which time the sheet reacts at different molarities solution and $25^{\circ} \mathrm{C}$. We have chosen approximately $3 \mathrm{~h}$ because in the fastest of those experiments studied, the $7 \mathrm{M}$ sheet is about to disappear, due to its small thickness of $0.02 \mathrm{~mm}$.

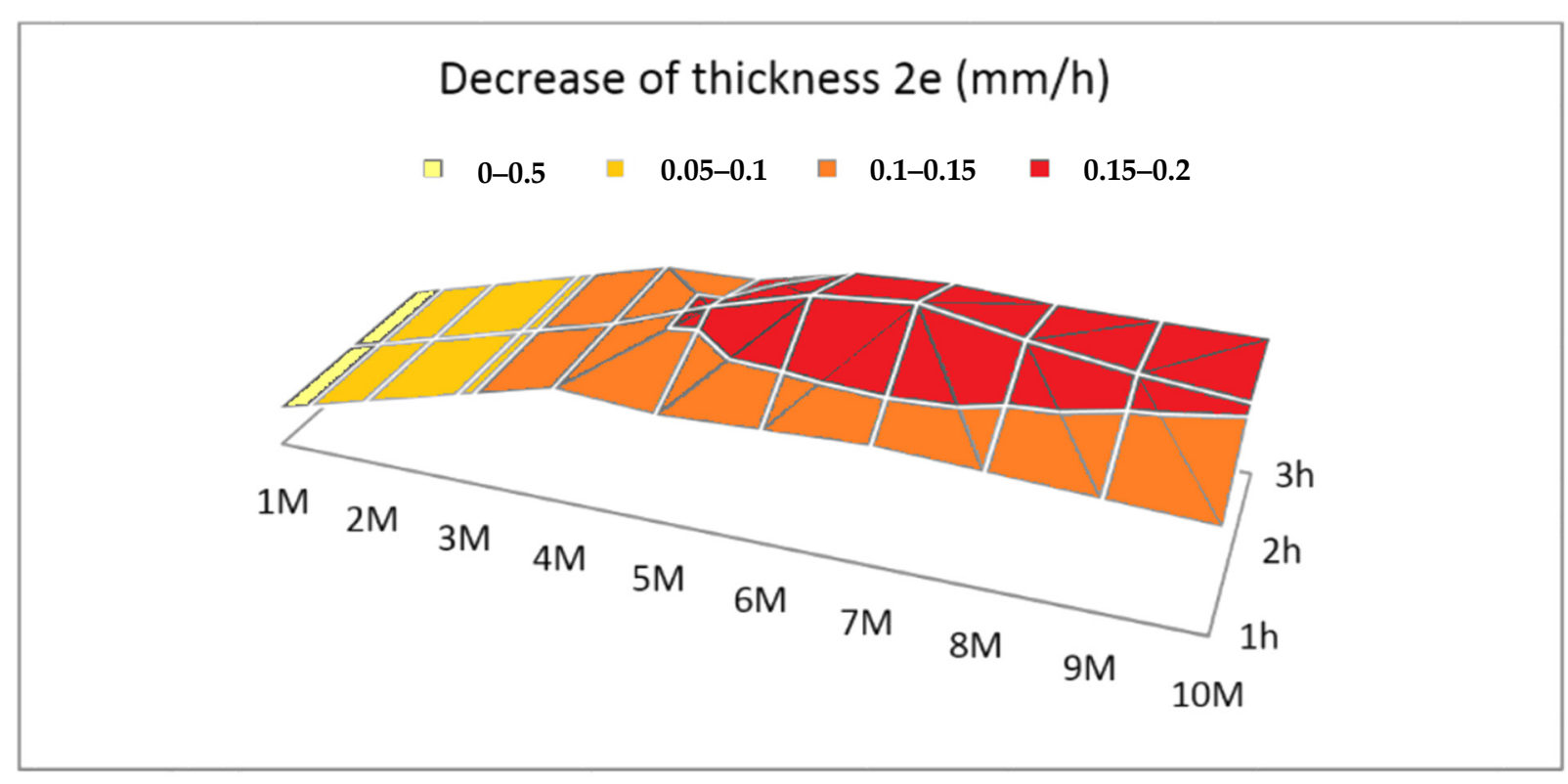

Figure 3. Decrease in the thickness $(2 e)$ of an aluminum foil $(\mathrm{mm} / \mathrm{h})$ at different molarities, at $25^{\circ} \mathrm{C}$, for $3 \mathrm{~h}$.

\subsubsection{Effect of Chip Size}

In the first test, the hydrogen generation from aluminum foil was analyzed, while in this second experiment 104 chips of the same initial active surface as the foil were analyzed, at $7.5 \mathrm{M}$, with alcohol and at $25^{\circ} \mathrm{C}$. The result is shown in Figure 4, in addition to the theoretical values obtained according to Equation (9).

In Figure 4, it is observed on the top graph how the hydrogen flow rate generated in the sheet is constant, staying between 5 and $4 \mathrm{~mL} / \mathrm{min}$, while with the chips the flow rate decreases more rapidly. This fact, as can be seen on the lower graph, is explained by the active surface, and given Equation (4), it is seen that it is reduced faster in the chips than in the sheet. Initially, for both typologies, there is enough active aluminum surface that the limiting factor is the water flow and thus the flow follows Equation (3). In the chips, after approximately half an hour (30 $\mathrm{min})$, the active surface is less than critical and the hydrogen flow then follows Equation (7), where the limiting factor is aluminum. It is checked that the time reaction depends on the thickness ( $p$ variable) in both formats. 

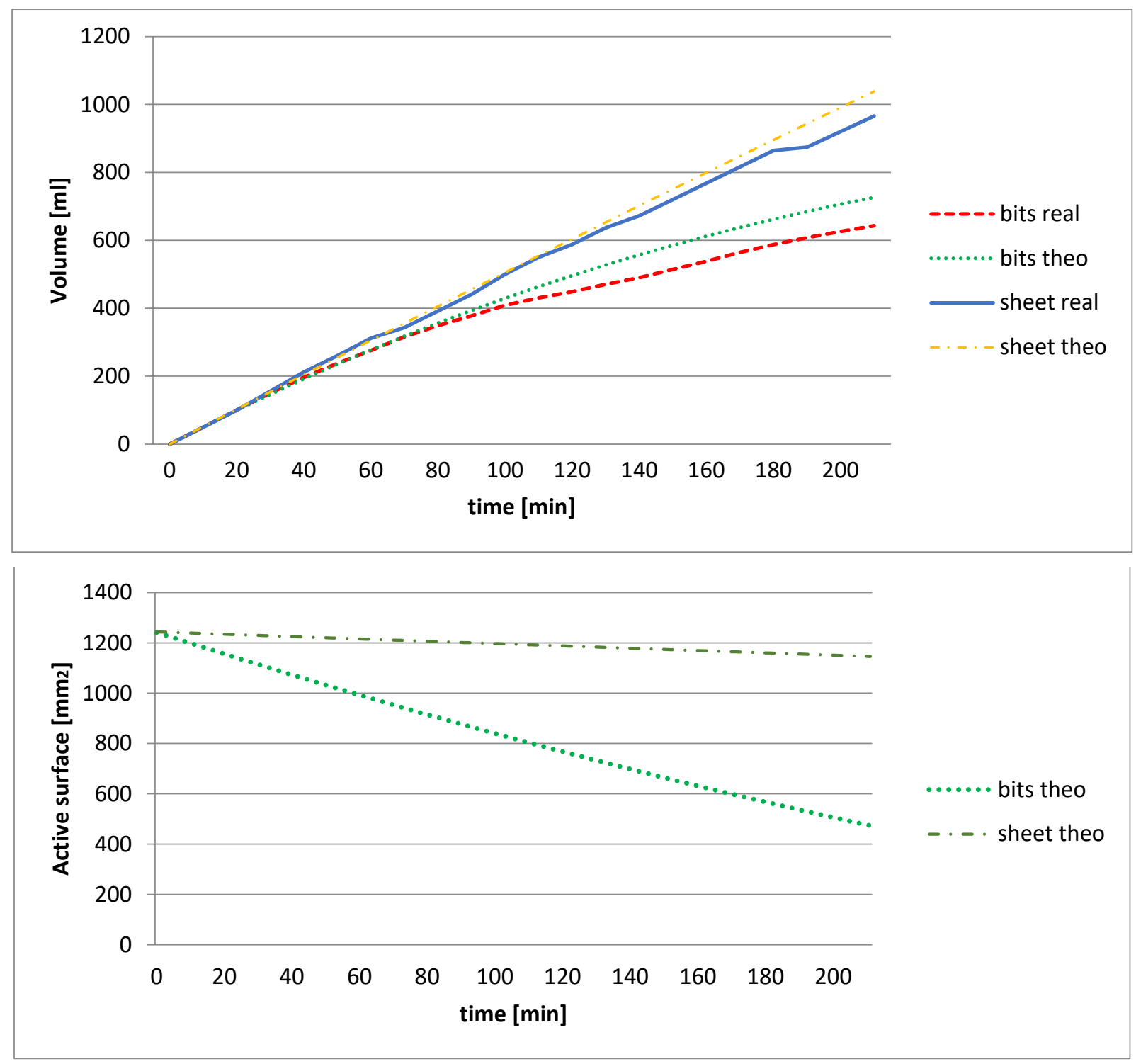

Figure 4. Comparison of the volume of hydrogen generated (in the figure above) from 104 sheet metal chips (chips) and a sheet (sheet), with the similar beginning active surface $\mathrm{NaOH}$ solution in a $7.5 \mathrm{M}$ (with isopropyl alcohol), at $25^{\circ} \mathrm{C}$ and its theoretical active surface as a function of time (in the figure below).

\subsubsection{Effect of Temperature}

In Equation (9), the effect of the temperature [39] has been validated by introducing aluminum sheets measuring $20 \times 30 \times 0.5 \mathrm{~mm}^{3}$ in a NaOH solution $(7.5 \mathrm{M})$, maintaining the constant temperature at $25^{\circ} \mathrm{C}, 40^{\circ} \mathrm{C}$ and $60^{\circ} \mathrm{C}$, observing that the theoretical active surface given in Equation (9) is perfectly adapted to the experimental one. In this case, the activation energy is $E_{a}=56.99 \mathrm{~kJ} \mathrm{~mol}^{-1}$. The comparison between the theoretical and experimental reduction is shown in Table 1. 
Table 1. Thickness reduction per surface $e$ at $7.5 \mathrm{M}$ as a function of temperature.

\begin{tabular}{ccc}
\hline Temperature $\left({ }^{\circ} \mathbf{C}\right)$ & $\begin{array}{c}\text { Theoretical Reduction of } \\
\text { Average Thickness } \\
(\mathbf{m m} / \mathbf{m i n})\end{array}$ & $\begin{array}{c}\text { Experimental Reduction of } \\
\text { Average Thickness } \\
\mathbf{( m m} / \mathbf{m i n})\end{array}$ \\
\hline 25 & 0.00125 & $0.00117 \pm 0.00003$ \\
\hline 40 & 0.00370 & $0.00365 \pm 0.00003$ \\
\hline 60 & 0.01410 & $0.01473 \pm 0.0003$ \\
\hline
\end{tabular}

In the case of ring cans in a $4 \mathrm{M} \mathrm{NaOH}$ solution, the temperature was kept constant at $50{ }^{\circ} \mathrm{C}$ and $60^{\circ} \mathrm{C}$. The comparison between the theoretical and experimental reduction is shown in Table 2.

Table 2. Thickness reduction per surface $e$ at $4 \mathrm{M}$ as a function of temperature.

\begin{tabular}{ccc}
\hline Temperature $\left({ }^{\circ} \mathbf{C}\right)$ & $\begin{array}{c}\text { Theoretical Thickness } \\
\text { Reduction }(\mathbf{m m} / \mathbf{m i n})\end{array}$ & $\begin{array}{c}\text { Experimental Thickness } \\
\text { Reduction }(\mathbf{m m} / \mathbf{m i n})\end{array}$ \\
\hline 50 & 0.00515 & $0.00516 \pm 0.00003$ \\
\hline 60 & 0.00986 & $0.00987 \pm 0.00003$ \\
\hline
\end{tabular}

\subsubsection{Adding Alcohol Effect}

Figure 5 shows the effect of isopropyl alcohol addition to $\mathrm{NaOH}$ solution. It worked with an aluminum sheet of $20 \times 30 \times 0.5 \mathrm{~mm}^{3}$ at $60^{\circ} \mathrm{C}$.

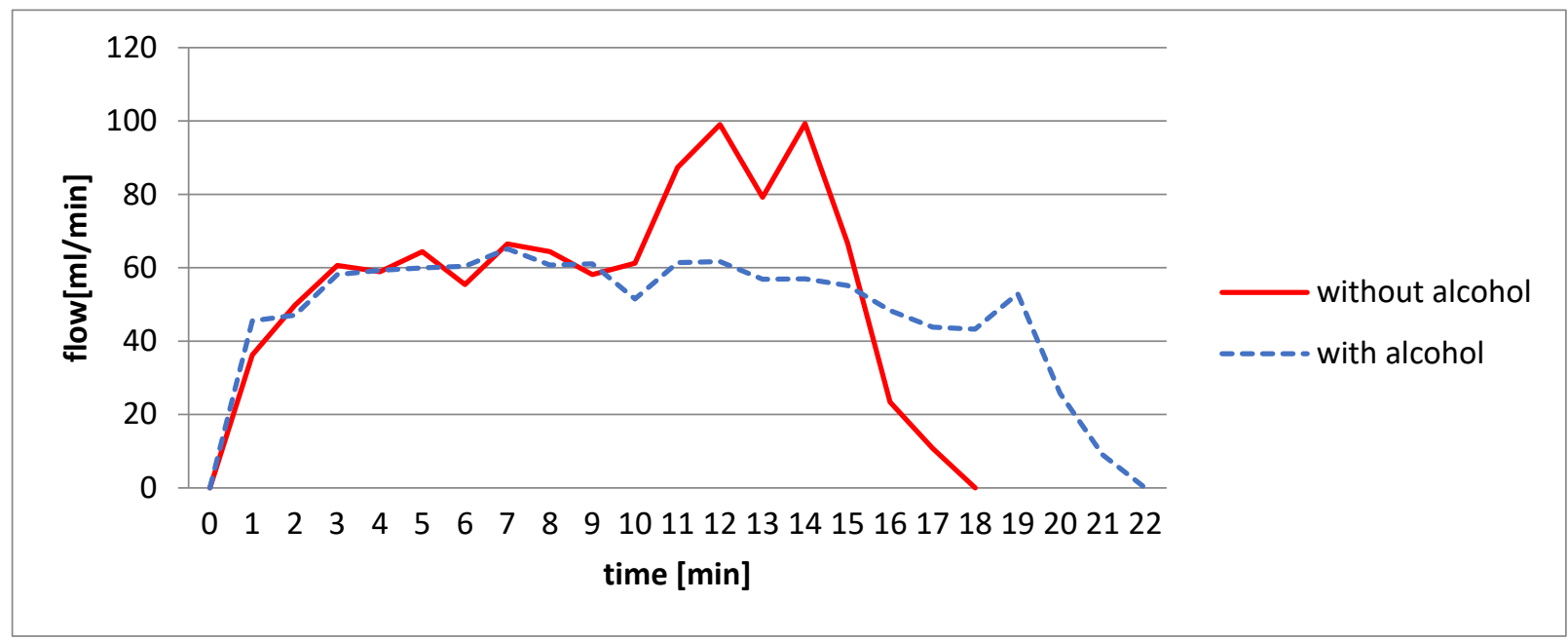

Figure 5. Hydrogen flow generated comparison $Q_{\left(H_{2}, t\right)}$ from a $7.5 \mathrm{M}$ sheet, with and without isopropyl alcohol at initially $60{ }^{\circ} \mathrm{C}$.

The alcohol used has a lower density than the $\mathrm{NaOH}$ solution 7.5 M [40]. Initially there are two phases; the upper phase is alcohol and the lower is soda solution. The sheets are submerged in the $\mathrm{NaOH}$ phase. As the aluminum-water reaction is exothermic, it increases the reactor temperature, and the hydrogen flow rate increases due to the corrosion rate and thickness reduction increase exponentially, too, as shown in table (Table 1). To achieve a constant flow, the system under control must ensure that the temperature is also constant. As the alcohol evaporates it maintains the temperature close to the boiling point. The other advantage of using alcohol is that the reaction can be controlled and stopped, as it does not react with aluminum, by controlling the alcohol level so that the aluminum is submerged in it. Moreover, the alcohol works as a reactive filter and does not allow the hydrogen to carry away the $\mathrm{NaOH}$ particles that can contaminate the fuel cell. Usually, to return the vaporized alcohol to the reactor, a condenser must be used [41]. 


\subsubsection{Hydrogen Purity}

The purity of the hydrogen produced with the sheets has been analyzed in anticipation that the aluminum residues could contain volatile or reactive elements that generate some undesirable gas. Gases such as CO, C1-C6 hydrocarbons or C1-C3 oxygenates were not detected on the micro gas chromatograph, nor were any alkali detected by $\mathrm{pH}$ analysis. For the flow generated, the purity of the hydrogen is greater than $98 \%$ in all the cases, with impurities of air $(<0.06 \%)$, alcohol $(<0.007 \%)$ and water $(>1.28 \%)$. This is due to the lack of tightness of the system connections since the equipment is made of glass or plastic and silicone tubes, which allows the passage of air into the circuit and the use of a water filter that generates more humidity than the dryer could absorb. The obtained alcohol after filtering, for hydrogen flow rates below $3 \mathrm{~L} / \mathrm{min}$, is not relevant $(<0.007 \%)$, but in the course of time, it is deposited in the filter and due to its low density, it can be dragged upstream inside the fuel cell.

\subsubsection{Prototype of a Vehicle with Hydrogen Fuel Cell from Aluminum Soda Rings}

In Figure 6, the flow calculated in the theoretical model is compared with the experimental flow produced by the 15 rings with $4 \mathrm{M} \mathrm{NaOH}$ solution. In the model, the rings have been simplified as sheets of $16 \times 25 \mathrm{~mm}^{2}$ with two holes with a radius of $5.1 \mathrm{~mm}$ and $4.7 \mathrm{~mm}$ thick. In the experiment, the temperature inside the generation tank and the intensity generated by the fuel cell at the working voltage was measured. It is verified that the flow obtained adapts to the theoretical model and how the alcohol regulates the start of the reaction, we have reduced to $4 \mathrm{M}$ the molarity to adapt the system to the required flow rate.

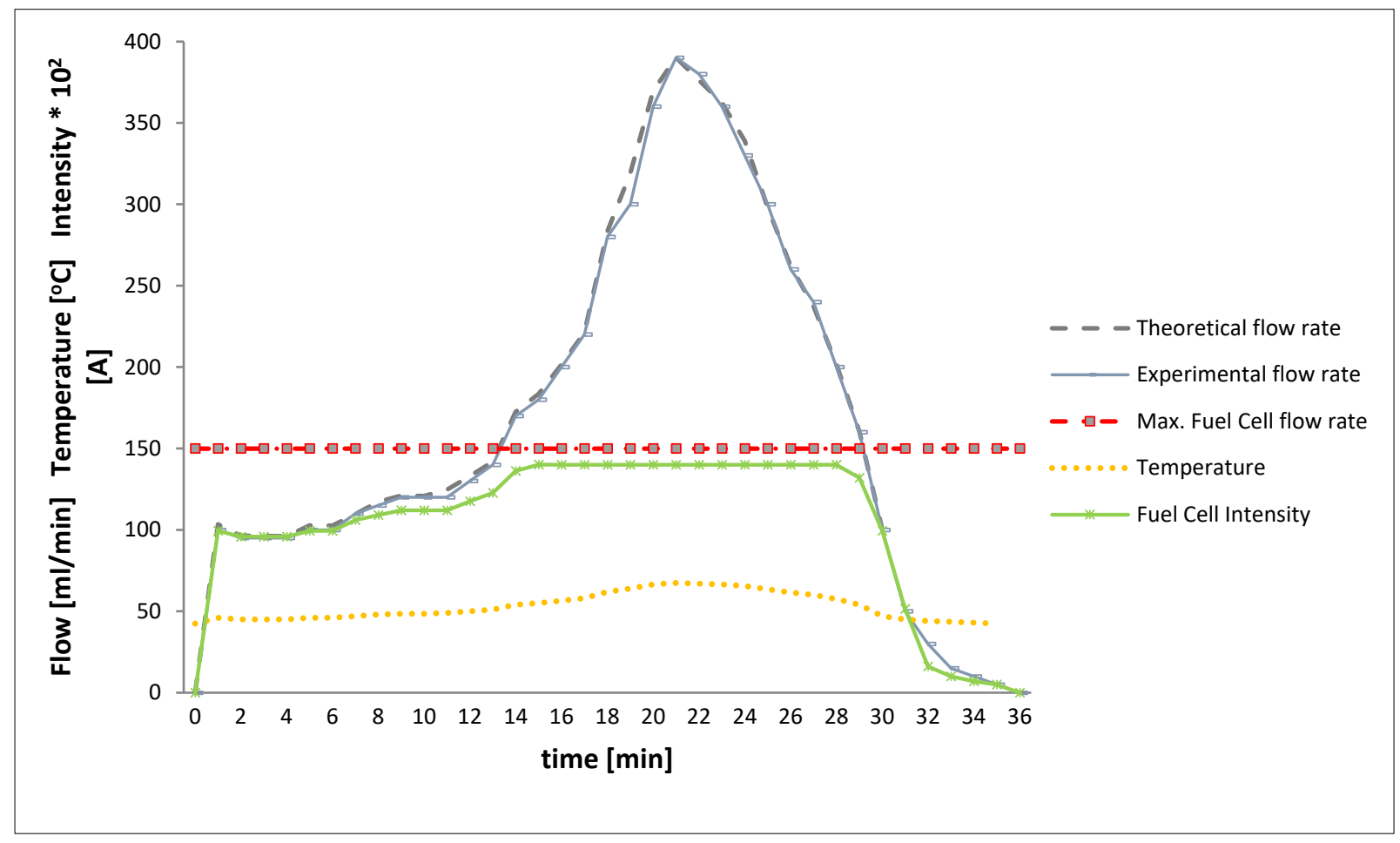

Figure 6. Theoretical hydrogen flow comparison of $Q_{\left(H_{2}, t\right)}$ produced from 15 rings and those obtained in the vehicle tank under the test conditions. The intensity generated by the fuel cell during the test is also shown. 


\section{Discussion}

About molarity, between $1 \mathrm{M}$ to $7.5 \mathrm{M}$, the reduction increases with the molarity. It is observed that between $1 \mathrm{M}$ and $4 \mathrm{M}$, the decrease in thickness is constant, but from $5 \mathrm{M}$, it increases non-linearly to $7.5 \mathrm{M}$. Between $7.5 \mathrm{M}$ and $10 \mathrm{M}$, it is reduced. According to the bibliography, it is because an increase in molarity leads to an increase in conductivity, which facilitates the reaction, but also leads to an increase in viscosity that harms the hydrogen generation [42]. It follows that the optimal point is at 7.5 M.

On the other hand, the alcohol is not capable of completely controlling the temperature due to the exothermic aluminum-water reaction. Since there is no condensation system in the vehicle, this prevents, in this case, the temperature from exceeding $68^{\circ} \mathrm{C}$; however, without alcohol, the hydrogen flow increases uncontrollably as it quickly exceeds $80^{\circ} \mathrm{C}$ and the cap of the tank is opened due to overpressure.

In the fuel cell, since the hydrogen is not completely pure, a power less than the expected $1.4 \mathrm{~A}$ is produced at $7.8 \mathrm{~V}[10.9 \mathrm{~W}]$ when the flow rate exceeds the $150 \mathrm{~mL} / \mathrm{min}$ required according to the manufacturer. If all the hydrogen generated was used by the fuel cells, the performance waste aluminum to hydrogen is $98 \%$ and the performance hydrogen to fuel cell power is around $93 \%$. The total balance energy performance is $91 \%$. In this RC car, the fuel cell outlet must be left open so that excess hydrogen is lost but could be stored by pressure. It is sufficient to charge the battery with the engine stopped and to help it while the vehicle is running, increasing its autonomy. At maximum power, the vehicle's engine consumes $2.4 \mathrm{~A}$ at $7.8 \mathrm{~V}$, so thanks to the fuel cell, the auxiliary battery needs to supply only $1 \mathrm{~A}$ at maximum power. The duration of the rings is approximately $30 \mathrm{~min}$ in operation, being $16 \mathrm{~min}$ at maximum power.

\section{Conclusions}

In this article, a new method is described to obtain high purity hydrogen from aluminum waste, at a constant flow rate, regardless of the amount of aluminum product in the fuel cell reactor, using isopropyl alcohol.

A theoretical model has been described that allows us to find the flow rate and the volume of hydrogen generated as a function of purity and dimensions of the aluminum sheets, as well as the molarity and temperature of the $\mathrm{NaOH}$ solution. To find the optimal solution, it is necessary to set the molarity and to determine the geometry and the corrosion rate of the material as the function of the temperature in each case.

The behavior of the aluminum-water reaction in the presence of alcohol at $25{ }^{\circ} \mathrm{C}$ at different molarities has been determined and described and it has been determined that the optimal concentration for maximum flow rate is $7.5 \mathrm{M}$. For molarities, between $1 \mathrm{M}$ and $4 \mathrm{M}$, the flow of hydrogen generated is constant because the reduction in thickness is constant in the course of time for a given temperature, while from $4 \mathrm{M}$, there are variations in the reduction in thickness in the course of time. For values greater than $7.5 \mathrm{M}$ the flow rate decreases.

It has been determined that it is important to obtain a constant flow that there is a sufficient active surface throughout the time, so it is preferable in this case to use sheet-like ring cans than little chips.

A theoretical model has been described to calculate the corrosion rate of the studied aluminum, which explains the reduction of the thickness of the sheet when reacting with a determined soda solution molarity in function of the temperature of the reaction, and the validation by means of the experimental tests.

We have described the effect of isopropyl alcohol which is the control of the reaction temperature below $70{ }^{\circ} \mathrm{C}$ and the filtration of the hydrogen generated, which simplifies the generation system. Purity tests and behavior analyses have been performed in other previous works in the laboratory with different types of aluminum chips, and the system generates a constant flow rate, with a purity of at least $98 \%$ with no contaminants that could damage the fuel cell, with low presence of water $(>1.28 \%)$, also air if the system is not well purged and alcohol of $<0.007 \%$. 
The system has been tested in a mobile machine, RC car with a $12 \mathrm{~W}$ fuel cell, with a low-cost generator and filter using 15 soda rings, $4 \mathrm{M} \mathrm{NaOH}$ solution and isopropyl alcohol. The performance waste aluminum to the fuel cell has been reduced by $9 \%$ compared to pure hydrogen, if we take advantage of all of the hydrogen generated. Fuel cells can supply 1.4 $\mathrm{A}$ at maximum power. The duration of the rings is approximately $30 \mathrm{~min}$ in operation, being $16 \mathrm{~min}$ at maximum power, but after that, the system can recharge quickly and keep working.

The advantage of this system is that you can use a low-power fuel cell machine with little cost and be able to recycle all the waste.

Author Contributions: X.S.-B.: conceptualization, methodology, formal analysis, supervision, project administration, funding acquisition. M.M.-G.: software, validation, visualization, writing-review \& editing, writing_original draft preparation; J.M.D.-M.: investigation, resources; L.M.V.: data curation. All authors have read and agreed to the published version of the manuscript.

Funding: This research received no external funding.

Institutional Review Board Statement: Not applicable.

Informed Consent Statement: Not applicable.

Data Availability Statement: Not applicable.

Conflicts of Interest: The authors declare no conflict of interest.

\section{References}

1. Tabbi, W.; Alaswad, A.; Palumbo, A.; Dassisti, M.; Olabi, A.G. Advances in stationary and portable fuel cell applications. Int. J. Hydrog. Energy 2016, 41, 16509-16522. [CrossRef]

2. Ramin, M.; Katrina, M.G. Hydrogen storage and delivery: Review of the state of art technologies and risk and reliability analysis. Int. J. Hydrog. Energy 2019, 44, 12254-12269.

3. Kundn, P.P.; Dutta, K. Hydrogen fuel cells for portable applications. Compend. Hydrog. Energy 2016, 4, 111-131. [CrossRef]

4. Neda, A.; Ghasem, N.-D. A comprehensive review on biological hydrogen production. Int. J. Hydrog. Energy 2020, 45, 22492-22512.

5. Atilla, E.; Hayati, O.; Sibel, O. Reforming options for hydrogen production from fossil fuels for PEM fuel cells. J. Power Sources 2006, 154, 67-73.

6. Sui, J.; Chen, Z.; Wang, C.; Wang, Y.; Liu, J.; Li, W. Efficient hydrogen production from solar energy and fossil fuel via waterelectrolysis and methane-steam-reforming hybridization. Appl. Energy 2020, 276, 115409. [CrossRef]

7. Nikolaidis, P.; Poullikkas, A. A comparative overview of hydrogen production processes. Renew. Sustain. Energy Rev. 2017, 67, 597-611. [CrossRef]

8. Xie, X.; Cui, N.; Wang, B.; Zhang, Y.; Zhao, X.; Lin, L.; Wang, B.; Du, W. Recent advances in hydrogen generation process via hydrolysis of Mg-based materials: A short review. J. Alloys Compd. 2020, 816, 152634. [CrossRef]

9. Khzouz, M.; Gkanas, E.I. Hydrogen Technologies for Mobility and Stationary Applications: Hydrogen Production, Storage and Infrastructure Development. Renew. Energy Resour. Chall. Appl. 2020, 255. [CrossRef]

10. Guo, J.; Chen, P. Catalyst: NH3 as an Energy Carrier. Chem 2017, 3, 709-712. [CrossRef]

11. Tomoda, K.; Hoshi, N.; Haruna, J.; Cao, M.; Yoshizaki, A.; Hirata, K. Hydrolysis Rate Improvement in Hydrogen Generation System Fueled by Powdery Sodium Borohydride for Fuel-Cell Vehicle. IEEE Trans. Ind. Appl. 2013, 50, 2741-2748. [CrossRef]

12. Abdelhamid, H.N. A review on hydrogen generation from the hydrolysis of sodium borohydride. Int. J. Hydrog. Energy 2021, 46, 726-765. [CrossRef]

13. Taylor, G.; Jason, R.; Gabl, T.; Pourpoint, L. Portable Power Generation for remote areas using hydrogen generated via maleic acid-promoted hydrolysis of ammonia borane. Molecules 2019, 24, 4045.

14. Tekade, S.P.; Pednekar, A.S.; Jadhav, G.R.; Kalekar, S.E.; Shende, D.Z.; Wasewar, K.L. Hydrogen generation through water splitting reaction using waste aluminum in presence of gallium. Int. J. Hydrog. Energy 2020, 45, 23954-23965. [CrossRef]

15. Dudoladov, A.; Buryakovskaya, O.; Vlaskin, M.; Zhuk, A.; Shkolnikov, E. Generation of hydrogen by aluminium oxidation in aquaeous solutions at low temperatures. Int. J. Hydrog. Energy 2016, 41, 2230-2237. [CrossRef]

16. Lin, Y.; Genzer, J.; Dickey, M.D. Attributes, Fabrication, and Applications of Gallium-Based Liquid Metal Particles. Adv. Sci. 2020, 7, 2000192. [CrossRef]

17. Macanás, J.; Soler, L.; Candela, A.M.; Muñoz, M.; Casado, J. Hydrogen generation by aluminum corrosion in aqueous alkaline solutions of inorganic promoters: The AlHidrox process. Energy 2011, 36, 2493-2501. [CrossRef]

18. Bolt, A.; Dincer, I.; Agelin-Chaab, M. A Review of Unique Aluminum-Water Based Hydrogen Production Options. Energy Fuels 2021, 35, 1024-1040. [CrossRef]

19. Trowell, K.A.; Goroshin, S.; Frost, D.L.; Bergthorson, J.M. Aluminum and its role as a recyclable, sustainable, carrier of renewable energy. Appl. Energy 2020, 275, 115112. [CrossRef] 
20. Huang, X.; Liu, S. On-Demand Hydrogen Generator Based on the Reaction between Aluminum Slurry and Alkaline Solution. Adv. Mater. Res. 2012, 347-353, 3242-3245. [CrossRef]

21. Razavi-Tousi, S.S.; Szpunar, J. Effect of structural evolution of aluminum powder during ball milling on hydrogen generation in aluminum-water reaction. Int. J. Hydrog. Energy 2013, 38, 795-806. [CrossRef]

22. Hakenjos, A.; Muenter, H.; Wittstadt, U.; Hebling, C. A PEM fuel cell for combined measurement of current and temperature distribution, and flow field flooding. J. Power Sources 2004, 131, 213-216. [CrossRef]

23. Wu, E.D.; Shi, P.F.; Du, C.D. A mini-type hydrogen generator from aluminium for proton exchange membrane fuel cells. J. Power Sources 2008, 181, 144-148.

24. Petrovic, J.; Thomas, G. Reaction of Aluminum with Water to Produce Hydrogen. A Study of Issues Related to the Use of Aluminum for On-Board Vehicular Hydrogen Storage. U. S. Dep. Energy 2008, 1, 1-26.

25. Bolt, A.; Dincer, I.; Agelin-Chaab, M. Energy and exergy analyses of hydrogen production process with aluminum and water chemical reaction. Energy 2020, 205, 117978. [CrossRef]

26. Parmuzina, A.V.; Kravchenko, O.V.; Bulychev, B.M.; Shkol'Nikov, E.I.; Burlakova, A.G. Oxidation of activated aluminum with water as a method for hydrogen generation. Russ. Chem. Bull. 2009, 58, 493-498. [CrossRef]

27. Huang, X.; Gao, T.; Pan, X.; Wei, D.; Lv, C.; Qin, L.; Huang, Y. A review: Feasibility of hydrogen generation from the reaction between aluminum and water for fuel cell applications. J. Power Sources 2013, 229, 133-140. [CrossRef]

28. Wang, K.; Eom, S.; Cho, E.A.; Kwon, H. Feasibility of on-board hydrogen production from hydrolysis of AlFe alloy for PEMFCs. Int. J. Hydrog. Energy 2011, 36, 12338-12342.

29. Zhang, Q.; Schulze, M.; Gazdzicki, P.; Friedrich, K.A. Comparison of different performance recovery procedures for polymer electrolyte membrane fuel cells. Appl. Energy 2021, 302, 117490. [CrossRef]

30. Salueña-Berna, X.; Mujal-Rosas, R.; Dagà-Monmany, J.M.; Martínez-López, J. Aprovechamiento de residuos de aluminio industrial para la obtención controlada de hidrógeno mediante la reacción aluminio-agua. Afinidad Rev. Quím. Teór. Apl. 2016, 49, 269-277.

31. Razavi-Tousi, S.; Szpunar, J. Mechanism of Corrosion of Activated Aluminum Particles by Hot Water. Electrochim. Acta 2014, 127, 95-105. [CrossRef]

32. Shaytura, N.S.; Laritchev, N.M.; Laritcheva, O. Study of the texture of hydroxides formed by aluminum oxidation with liquid water at various activation techniques Current. Appl. Phys. J. 2010, 10, S66-S68.

33. Teng, H.-T.; Lee, T.-Y.; Chen, Y.-K.; Wang, H.-W.; Cao, G. Effect of $\mathrm{Al}(\mathrm{OH})_{3}$ on the hydrogen generation of aluminum-water system. J. Power Sources 2012, 219, 16-21. [CrossRef]

34. Hu, H.; Qiao, M.; Pei, Y.; Fan, K.; Li, H. Kinetics of hydrogen evolution in alkali leaching of rapidly quenched Ni-Al alloys. Appl. Catal. A Gen. 2003, 252, 173-183. [CrossRef]

35. Mahmoodi, K.; Alineiad, B. Enhancement of hydrogen generation rate in reaction of aluminum with water. Int. J. Hydrog. Energy 2010, 35, 5227-5232. [CrossRef]

36. Miadoková, M.; Molnárová-Plchová, M. kinetics and mechanism of the reaction of aluminum in aqueous solution of sodium hydroxide. Chem. Pap. 1985, 39, 229-235.

37. Aleksandrov, Y.A.; Tsyganova, E.I.; Pisarev, A.L. Reaction of Aluminum with Dilute Aqueous NaOH Solutions. Russ. J. Gen. Chem. 2003, 73, 689-694. [CrossRef]

38. Gomma, G.K.; Wahdan, M.H. Schiff bases as corrosion inhibitors for aluminum in hydrochloric acid solution. Mater. Chem. Phys. 1995, 39, 209-213. [CrossRef]

39. Hiraki, T.; Takeuchi, M.; Hisa, M.; Akiyama, T. Hydrogen Production from Waste Aluminum at Different Temperatures, with LCA. Mater. Trans. 2005, 46, 1052-1057. [CrossRef]

40. Park, Y.K.; Tadd, E.H.; Zubris, M.; Tannenbaum, R. Size-controlled synthesis of alumina nanoparticles from aluminum alkoxides. Mater. Res. Bull. 2005, 40, 1506-1512. [CrossRef]

41. Berna, X.S.; Marín-Genescà, M.; Dagà-Monmany, J. Analysis of Valorization Process of Aluminum Breakage Scraps to Obtain Green Hydrogen. Metals 2021, 11, 598. [CrossRef]

42. Wang, S.; Zhu, L.; Zhang, L.; Zhang, X.; Wang, X.; Ge, M.; Li, X.; Zou, M. Preparation of Al-3Ga-3In-3Sn Alloy Powder by Coupling Alloying and Ball Milling and Its Application on High-Rate Hydrogen Generation at Room Temperature. Metals 2021, 11, 1704. [CrossRef] 